\title{
Is Aromatization of Testosterone to Estradiol Required for Inhibition of Luteinizing Hormone Secretion in Men?
}

\author{
Richard J. SANTEN \\ From the Department of Medicine, Division of Endocrinology, The Milton S. \\ Hershey Medical Center of The Pennsylvania State University, \\ Hershey, Pennsylvania 17033
}

A в S T R A C T A variety of studies in man and animals demonstrate that testosterone $(\mathrm{T})$ is aromatized to estradiol $(E)$ in the hypothalamus and limbic system. These observations suggested the possibility that conversion to $\mathrm{E}$ is an absolute requirement for the biologic activity of $\mathrm{T}$ on the hypothalamic-pituitary axis. Since this hypothesis implies a common mechanism of action of these two steroids, the demonstration of divergent effects of $T$ and $\mathrm{E}$ on luteinizing hormone $(\mathrm{LH})$ secretion would exclude this possibility. To test this hypothesis, the actions of $\mathrm{T}$ and $\mathrm{E}$ on three separate aspects of $\mathrm{LH}$ release (mean $\mathrm{LH}$, pulsatile $\mathrm{LH}$ secretion, and responsiveness to $\mathrm{LH}$ releasing hormone $[\mathrm{LH}-\mathrm{RH}]$ ) were contrasted. $\mathrm{T}$ and $\mathrm{E}$, infused at two times their respective production rates into normal men, reduced mean LH levels similarly during $6 \mathrm{~h}$ of steroid infusion and for $6 \mathrm{~h}$ thereafter. However, these steroids exerted different effects on pulsatile secretion. $\mathrm{E}$ reduced the amplitude of spontaneous $\mathrm{LH}$ pulses from pre- and postinfusion control levels of $75 \pm 14$ and $68 \pm 5.6 \%$ (SEM) to $39 \pm 5.7 \%$. In contrast, $\mathrm{T}$ increased pulse amplitude to $96 \pm 14 \%$ and decreased pulse frequency from basal levels of $3.4 \pm 0.31$ to $1.8 \pm$ 0.31 pulses $/ 6 \mathrm{~h}$.

The site of suppressive action was determined by administering $25 \mu \mathrm{g}$ of $\mathrm{LH}-\mathrm{RH}$ to the same men during $\mathrm{T}$ and $\mathrm{E}$ infusions and during three additional control periods without steroid administration. LH-RH produced similar $170-190 \%$ increments in serum $\mathrm{LH}$ during the three control periods and during $\mathrm{T}$ infusion. In contrast, E markedly blunted $(76 \pm 31 \%, P<0.005)$ the $\mathrm{LH}$ response to LH-RH. Under the conditions of acute steroid infusion at doses (utilized in these experiments) pro-

This study was presented in part at the 56th Annual Meeting of the Endocrine Society and also in part at The American Federation of Clinical Research National Meeting, Atlantic City, N. J., 3-5 May 1975.

Received for publication 28 February 1975 and in revised form 21 August 1975. ducing similar inhibition of mean $\mathrm{LH}, \mathrm{E}$ but not $\mathrm{T}$ acted directly on the pituitary to diminish LH-RH responsiveness.

As further support that androgens can act without conversion to estrogens, the effects of a nonaromatizable androgen, dihydrotestosterone (DHT), on mean LH levels were studied. DHT, infused at the same rate as T, suppressed mean $\mathrm{LH}$ to a similar but somewhat greater extent than $\mathrm{T}$. Since $\mathrm{T}$ and $\mathrm{E}$ produced divergent effects on LH secretion and a nonaromatizable androgen, DHT, suppressed mean $\mathrm{LH}$, aromatization is not a necessary prerequisite for the action of androgens on the hypothalamic-pituitary axis.

\section{INTRODUCTION}

Estradiol $(E)^{1}$ can reproduce a number of the effects of testosterone ( $T$ ) on the central nervous system (CNS) in animals and in man. Immature female rodents respond similarly to $\mathrm{E}$ and $\mathrm{T}$ during a critical neonatal period by developing a male, noncyclic pattern of gonadotropin secretion (1-2). In men, microgram amounts of $\mathrm{E}$ suppress plasma LH levels to the same extent as milligram amounts of $\mathrm{T}$ (3-4). To explain the common actions of these steroids, Naftolin et al. postulated that $\mathrm{T}$ may be converted into $\mathrm{E}$ in the brain (5). Testing this hypothesis, they demonstrated aromatizing enzyme systems capable of metabolizing $T$ to $E$ in the hypothalamus and limbic system of various species, including man (5-9). The $E$ produced locally from $T$ could then bind to cytoplasmic and nuclear receptors (10-13) to initiate hormone action. This precursor to product relationship between $\mathrm{T}$ and $\mathrm{E}$ would be analogous to the interaction in peripheral tissues between $T$

\footnotetext{
${ }^{1}$ Abbreviations used in this paper: CNS, central nervous system; DHT, dihydrotestosterone; E, estradiol ; LH-RH, LH-releasing hormone; $\mathrm{T}$, testosterone.
} 
as a prohormone and its biologically active metabolite, dihydrotestosterone (DHT).

These observations have been interpreted as evidence that $\mathrm{T}$ serves exclusively as a prohormone in the brain and requires aromatization to $E$ for biologic activity on the hypothalamic-pituitary axis. However, since this hypothesis implies a common mechanism of action of $\mathrm{T}$ and $\mathrm{E}$, the demonstration of divergent effects of these steroids on the CNS would argue against this possibility. In this study, a practical and sensitive means of comparing the biologic effects of $\mathrm{T}$ and $\mathrm{E}$ on the hypothalamic-pituitary axis was developed to distinguish possible differences between these two steroids. This method involved determination of the 6 - $h$ mean luteinizing hormone ( $\mathrm{LH}$ ) to integrate fluctuating hormone levels, analysis of pulsatile LH secretion, and assessment of LH-releasing hormone ( $\mathrm{LH}-\mathrm{RH}$ ) responsiveness during both $\mathrm{T}$ and $\mathrm{E}$ infusions. A direct means of studying the role of androgens per se was also used and involved the infusion of DHT. Since this steroid cannot be converted to $\mathrm{E}$, the demonstration of $\mathrm{LH}$ suppression with DHT would suggest that androgens can act independently on the hypothalamic pituitary axis. Using these separate approaches, the studies to be reported examined whether aromatization of $\mathrm{T}$ to $\mathrm{E}$ is required for inhibition of $\mathrm{LH}$ secretion in men.

\section{METHODS}

\section{Hormone assays}

Serum LH levels were measured by a double-antibody radioimmunoassay system similar to that previously described (14). Human chorionic gonadotrophin, lot no. E289-TER-2, supplied by Serono Laboratories, Inc. (Boston, Mass.) was used as a trace for radioiodination. With this system, the lower limit of detectability, using $200 \mu \mathrm{l}$ of plasma was $9 \mathrm{ng}$ of LER $907 / \mathrm{ml}$. The within assay co-

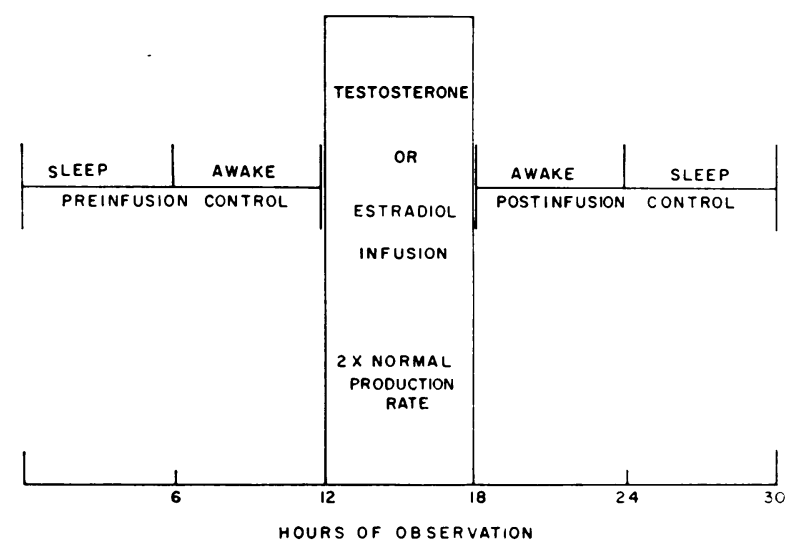

Figure 1 Protocol used for study of $\mathrm{LH}$ secretion in man. Blood samples are collected at 20 -min intervals throughout the 30 -h period. efficient of variation of duplicate samples ranged from 3.8 to $6.7 \%$ at portions of the standard curve representing 20 $80 \%$ binding. All samples from the same individual in a given study were run in the same assay. Plasma T, DHT, and $\mathrm{E}$ were also determined by radioimmunoassay after column chromatography $(15,16)$. The between assay coefficient of variation of these assays is less than $20 \%$ and within assay coefficient of variation is less than $10 \%$, respectively.

\section{Subjects}

12 men between the ages of 23 and 31 agreed to participate in this study and serve as normal volunteers. Each subject admitted to a normal frequency of shaving as well as normal libido and potentia. On physical examination, each had normal adult size testes and adult male pubic and axillary hair distribution. Basal plasma LH, follicle-stimulating hormone, and $\mathrm{T}$ levels in all subjects were within the normal range.

\section{Analysis of functional and anatomic aspects of LH secretion}

\section{MEAN LH LEVELS}

$\mathrm{LH}$ release is a nonsteady state process and spontaneous pulses of secretion occur on the average of once every $2 \mathrm{~h}$ $(14,17-22)$. In examining acute LH suppression with physiologic amounts of gonadal steroids, the $20-30 \%$ reduction in secretion rate expected could not be easily detected in the presence of spontaneous $\mathrm{LH}$ pulses with the magnitude of $20-400 \%$. A means of integrating LH pulses was therefore necessary to demonstrate small changes in overall secretion. Studies from this laboratory have previously shown that the mean $\mathrm{LH}$ level, obtained from 18 samples collected over $6 \mathrm{~h}$, correlates well with integrated $\mathrm{LH}$ and allows detection of a $12 \%$ change in $\mathrm{LH}$ secretion (14). Consequently, this approach was chosen to quantitate the acute suppressive effects of $T$ and $E$.

\section{Pulsatile lh Release}

Pulsatile $\mathrm{LH}$ secretion can be characterized as to its inherent amplitude, frequency, and decay. "Pulse analysis" may allow insight into the physiological mechanisms of negative feedback suppression and provide a means of discriminating between the effects of $\mathrm{T}$ and $\mathrm{E}$. Automated analysis of LH pulse amplitude, frequency, and decay (apparent half-life) were carried out using a computer program previously described (14). An LH pulse is defined as an abrupt rise in $\mathrm{LH}$ of greater than $20 \%$ from nadir to peak. Pulse amplitude ${ }^{2}$ refers to the percent increment from nadir to peak in LH per secretory pulse. Frequency is the number of pulses $/ 6 \mathrm{~h}$. Decay or "apparent half-life" is defined as the half time of the log linear decrement of LH in serum, lasting at least $40 \mathrm{~min}$.

\section{Responsiveness to LH-RH}

To determine the anatomic site of suppression of $\mathrm{T}$ and $\mathrm{E}$, artificial LH pulses were induced by administering exogenous LH-RH during steroid infusions. Mean LH levels

\footnotetext{
${ }^{2}$ In previous communications, absolute pulse amplitude expressed as nanograms LH rise per pulse was also analyzed. For simplification of presentation, only percentage changes are recorded in this communication since both analyses yielded similar results.
} 
measured during $3 \mathrm{~h}$ before $\mathrm{LH}-\mathrm{RH}$ administration were compared to mean $\mathrm{LH}$ levels for $3 \mathrm{~h}$ after injection. Responses were expressed as absolute and percentage increments in plasma $\mathrm{LH}$.

\section{Study protocols}

\section{EFFECTS OF T AND E INFUSION ON LH SECRETION}

Effects on mean LH. The protocol outlined in Fig. 1 was carried out on six normal men observed for $30 \mathrm{~h}$. The study was divided into three intervals which included: (a) a 12-h preinfusion control period during both sleep and waking hours; $(b)$ a 6 -h infusion of $\mathrm{T}(600 \mu \mathrm{g} / \mathrm{h})$ at two times its normal production rate; and (c) a 12-h postinfusion control period during sleep and waking. An identical protocol was repeated $2-4$ wk later on the same six subjects except that $E(3.5 \mu \mathrm{g} / \mathrm{h})$ was the steroid infused at two times its normal production rate. Blood samples for $\mathrm{LH}, \mathrm{T}$, and $\mathrm{E}$ levels were collected at 20 -min intervals through a heparin well scalp-vein needle throughout both $30-h$ study periods. The sera obtained from all blood samples were frozen at $-20^{\circ} \mathrm{C}$ and stored for later assay of $\mathrm{LH}$ and calculation of mean $\mathrm{LH}$ levels.

Pulsatile $\mathrm{LH}$ release. The blood samples collected during the protocol described above (mean $\mathrm{LH}$ ) were also used for analysis of pulsatile $\mathrm{LH}$ release.

Responsiveness to $L H-R H$. Five of the same six men and one additional subject were restudied 5-8 mo later. To obviate the possibility of diminished responses to repeated LH-RH injections, we altered the protocol used above so that each control and steroid infusion period was carried out on a separate day. Blood was collected during individual studies at 20-min intervals for $3 \mathrm{~h}$ before (5-8 p.m.) and $3 \mathrm{~h}$ after (8-11 p.m.) administration of $25 \mu \mathrm{g}$ of LH-RH (at 8 p.m.). Previous data indicated that this dose of LH-RH produced a half-maximal LH response (23). Individual study days (as designated on Table II) consisted of the following: day 1, preinfusion control: response to LH-RH during control period; day 2, $\mathrm{E}$ infusion: response to $\mathrm{LH}-\mathrm{RH}$ during $\mathrm{E}$ infusion; day 3 , postinfusion and preinfusion controls: ${ }^{3}$ response to $\mathrm{LH}-\mathrm{RH}$ during control period; day 4, T infusion: response to LH-RH during $T$ infusion; day 5, postinfusion control: response to $\mathrm{LH}-\mathrm{RH}$ during control period. On day 2, $\mathrm{E}$ was infused for $6 \mathrm{~h}$ (5-11 p.m.) and on day 4, $T$ was infused using the exact methods and steroid dosage (two times the normal production rate) as for mean $\mathrm{LH}$ and pulsatile $\mathrm{LH}$ studies.

\section{THE EFFECTS OF DHT ON LH SECRETION}

In five additional men, the effects of DHT on mean $\mathrm{LH}$ and pulsatile $\mathrm{LH}$ secretion were determined. The protocol used for studies of $T$ and $E$ was followed exactly (Fig. 1) with the exception that DHT $(600 \mu \mathrm{g} / \mathrm{h})$ was the steroid infused.

\section{Methodology for steroid infusions and plasma concentrations attained}

Infused steroids were recrystallized, dissolved in $95 \%$ ethanol, and diluted 1:10 vol/vol in $0.9 \%$ sterile saline before use. Sialinized glassware and Teflon tubing were used for the preparation and infusion of the steroids by Harvard pump (Harvard Apparatus Co., Millis, Mass.). A

${ }^{3}$ For statistical analysis, day 3 was used both as the postinfusion control for the $\mathrm{E}$ protocol and the preinfusion control for the $T$ protocol. loading dose of steroid, equivalent to that received during $30 \mathrm{~min}$ of infusion, was administered by i.v. push followed by a constant infusion of the same steroid for $6 \mathrm{~h}$. T was infused at a rate of $600 \mu \mathrm{g}\left(12 \mathrm{~cm}^{3}\right) / \mathrm{h}$, an amount approximating twice the normal production of $\mathrm{T}$ in men $\left(\mathrm{PR}-\mathrm{T}_{\mathrm{b}}\right.$ $7.0 \mathrm{mg} / 24 \mathrm{~h})(24) . \mathrm{E}$ was also administered at a rate (3.5 $\mu \mathrm{g} / \mathrm{h}$ in $5 \mathrm{~cm}^{3}$ ) approximating twice its normal production in men (PR-E $E_{b} 45 \mu \mathrm{g} / 24 \mathrm{~h}$ ) (24). DHT was infused at the same rate at $\mathrm{T}(600 \mu \mathrm{g} / \mathrm{h})$, an amount representing 60 times its normal producion rate (PR-DHT $302 \mu \mathrm{g} / 24 \mathrm{~h}$ ) (25).

Plasma $\mathrm{T}$ levels rose twofold from relatively constant basal concentrations immediately after the start of the $T$ infusions, and in $6 \mathrm{~h}$, reached threefold elevations (Fig. 2A). After stopping the infusion, plasma $T$ concentrations fell to control levels within $3 \mathrm{~h}$. A significant conversion of $\mathrm{T}$ to $\mathrm{E}$ in blood occurred during the $\mathrm{T}$ infusion, resulting in a rise in plasma $E$ levels from $28 \pm 3$ to $48 \pm 4 \mathrm{pg} / \mathrm{ml}$
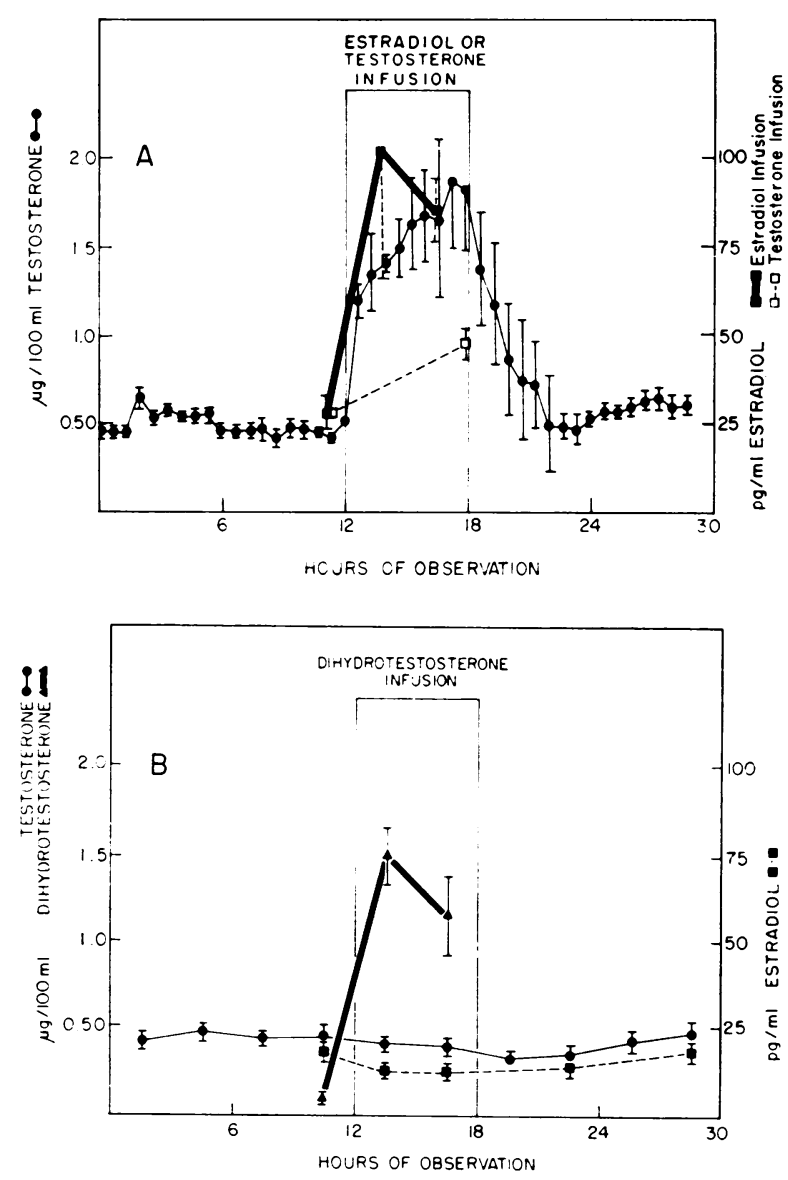

Figure 2 (A) Plasma steroid levels during $\mathrm{T}$ and $\mathrm{E}$ infusion studies. $\mathrm{T}$ infusion protocol: (৫), Mean plasma $T$ levels ( \pm SEM). ( $\square$ ), The $E$ concentration derived from infused $T$ was measured at the end of the $T$ infusion and is compared to basal levels. $E$ infusion protocol: ( $\square$ ), Plasma $\mathrm{E}$ levels before and during its infusion. The levels of $\mathrm{E}$ during infusion were determined in each individual by pooling plasma from the first $3 \mathrm{~h}$ and the second $3 \mathrm{~h}$ of infusion. (B) Plasma steroid levels during DHT infusion studies. 
(SEM) (Fig. 2A). During $E$ infusion, this steroid achieved even higher plasma levels $(103 \pm 35 \mathrm{pg} / \mathrm{ml})$ with peak concentrations similar to those found in the follicular phase of the menstrual cycle in normal women (26).

During DHT infusion, the plasma levels of this steroid rose from low basal levels to approximately $1.5 \mu \mathrm{g} / 100 \mathrm{ml}$ (Fig. 2B). T levels, on the other hand, diminished slightly during the infusion and fell further $(23 \%, P<0.05)$ after infusion before returning to basal levels in the final $6 \mathrm{~h}$ of study. E levels decreased from a mean of $18.6 \pm 2.5 \mathrm{pg} / \mathrm{ml}$ before infusion to $13.4 \pm 1.9 \mathrm{pg} / \mathrm{ml}(P<0.05)$ during infusion before returning to base line during the last $6 \mathrm{~h}$ of study.

\section{Statistical methods}

\section{MEAN LH}

Paired comparisons were employed to analyze the effects of $\mathrm{T}, \mathrm{E}$, and DHT on mean LH levels.

\section{Pulsatile LH AND LH-RH Responsiveness}

The experimental design allowed two separate comparisons to be made. First, the efiects of $\mathrm{T}$ were compared with those of $\mathrm{E}$ using paired $t$ tests. Second, the preand postinfusion control periods were compared with the steroid infusion period using a three-way, nonparametric sign test (27). This statistical method permitted us to use both pre- and postinfusion control periods simultaneously as controls for the treatment period. This approach was validated by establishing that pre- and postinfusion control periods were statistically indistinguishable (by paired $t$ test analysis) and could therefore both be used together as appropriate controls.

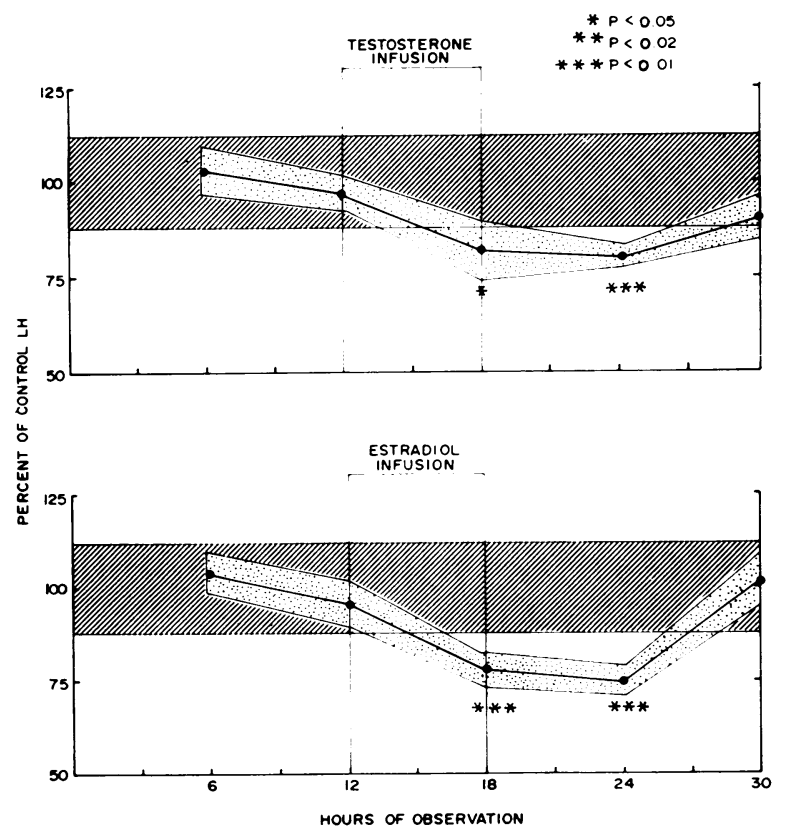

FIGURE 3 The effect of $\mathrm{T}$ and $\mathrm{E}$ infusions on mean $\mathrm{LH}$. 6-h mean LH levels are represented by the solid circles and the SEM by the shaded area. With this method (6-h mean LH), changes of greater than $\pm 12 \%$, cross-hatched area, are significant.

\section{RESULTS}

\section{Effects of $\mathrm{T}$ and $\mathrm{E}$ infusion on $\mathrm{LH}$ secretion}

\section{MeAN LH}

The effect of $\mathrm{T}$ and $\mathrm{E}$ infusions on mean $\mathrm{LH}$ levels are summarized in Fig. 3. During the $6 \mathrm{~h}$ of $\mathrm{T}$ administration, mean LH fell significantly to $82 \pm 7.8 \%$ of control levels and during $\mathrm{E}$ to $79 \pm 4.7 \%$. $\mathrm{LH}$ suppression continued for $6 \mathrm{~h}$ after both infusions before returning toward basal levels. Although it appeared that $\mathrm{LH}$ might rise more slowly in the final $6 \mathrm{~h}$ after $\mathrm{T}$ infusion, the LH levels of the $\mathrm{T}$ and $\mathrm{E}$ treatment groups did not differ significantly from each other at that time. Thus, the infusions of $\mathrm{T}$ and $\mathrm{E}$ produced similar suppression of mean LH levels, an important prerequisite for valid interpretation of pulsatile secretion analysis.

\section{Pulsatile lh Release}

Amplitude. $\quad \mathrm{T}$ significantly $(P<0.05)$ increased pulse amplitude above the pre- and postinfusion control levels of $65 \pm 5.4$ and $72 \pm 6.3 \%$, respectively, to $96 \pm$ $14 \%$ (Table I). In marked contrast, $\mathrm{E}$ administration resulted in a reduction of pulse amplitude $(39 \pm 5.7 \%)$ when compared to the $\mathrm{E}$ control periods (preinfusion $75 \pm 14 \%$, postinfusion $68 \pm 5.6 \%, P<0.02)$. Therefore, these steroids produced divergent effects on pulses with $\mathrm{T}$ increasing amplitude $(96 \pm 14 \%)$ and $\mathrm{E}$ decreasing it $(39 \pm 5.7 \%, P<0.02)$ in the same men.

Frequency. The $\mathrm{T}$ infusion significantly $(P<0.05)$ decreased the number of LH pulses observed in $6 \mathrm{~h}$ from $3.4 \pm 0.31$ to $1.8 \pm 0.31$. Furthermore, after $\mathrm{T}$ treatment, the number of pulses $/ 6 \mathrm{~h}$ returned to that of the preinfusion control period (3.4 \pm 0.53$)$. By contrast, $\mathrm{E}$ had no significant effect on pulse frequency (Table I).

Decay. This parameter remained constant during all control periods and during the steroid infusions (Table I).

\section{LH-RH RESPONSIVENESS}

Each subject was given LH-RH during three separate control periods without steroid infusion. While responses to $\mathrm{LH}-\mathrm{RH}$ were highly variable between subjects, each individual exhibited a similar $\mathrm{LH}$ increment in response to LH-RH during the 3 control days (days $1,3,5$ ). Consequently, mean increases of LH after LH-RH $(190 \pm 54,170 \pm 33,175 \pm 49)$ were indistinguishable during control days (Fig. 4, Table II). E significantly blunted the effect of LH-RH $(P<0.005)$ on $\mathrm{LH}$ release as mean increments during $E$ infusion (day 2) were only $76 \pm 31 \%$. In marked contrast, during $\mathrm{T}$ infusion (day 4), LH-RH produced the same increase in plasma $\mathrm{LH}$ levels as on the control days $(217 \pm 59 \%)$. Identical effects were detected whether responses were expressed as percent or absolute increments (Table II). 
TABLE 1

Effect of $T$ and E Infusion on Pulsatile LH Release

\begin{tabular}{|c|c|c|c|c|c|c|c|c|}
\hline \multirow{2}{*}{$\begin{array}{l}\text { Pulse analysis } \\
\text { parameter }\end{array}$} & \multirow[b]{2}{*}{ Subject } & \multicolumn{3}{|c|}{ E protocol* } & \multicolumn{3}{|c|}{ T protocol* } & \multirow{2}{*}{$\begin{array}{c}\text { T v8. E } \\
\text { infusion } \\
\text { period- } \\
\text { significance }\end{array}$} \\
\hline & & Preinfusion & Infusion & Postinfusion & Preinfusion & Infusion & Postinfusion & \\
\hline \multirow[t]{7}{*}{ Amplitude nadir-Peak, $¥ \%$} & 1 & 73 & 32 & 49 & 63 & 80 & 70 & \\
\hline & 2 & 142 & 40 & - & 89 & 143 & 39 & \\
\hline & 3 & 67 & 28 & 84 & 53 & 112 & 78 & \\
\hline & 4 & 67 & 27 & 75 & 69 & 116 & 84 & \\
\hline & 5 & 51 & 43 & 54 & 57 & 50 & 71 & \\
\hline & 6 & 53 & 65 & 73 & 60 & 72 & 73 & \\
\hline & Mean \pm SEM & $75 \pm 14$ & $\begin{array}{c}39 \pm 5.7 \\
P<0.028\end{array}$ & 68.5.6 & $65 \pm 5.4$ & $\begin{array}{c}96 \pm 14 \\
-P<0.05\end{array}$ & 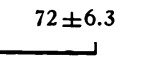 & $P<0.02$ \\
\hline \multirow[t]{7}{*}{ Frequency, pulses/ $6 h$} & 1 & 3.5 & 2 & 3 & 4 & 3 & 2 & \\
\hline & 2 & 1.5 & 4 & - & 2 & 2 & 2 & \\
\hline & 3 & 4 & 1 & 2.5 & 3.5 & 2 & 3 & \\
\hline & 4 & 3 & 1 & 2.5 & 4 & 1 & 3.5 & \\
\hline & 5 & 4 & 3 & 3.5 & 3.5 & 1 & 3 & \\
\hline & 6 & 3 & 3 & 3 & 3 & 2 & 4 & \\
\hline & Mean \pm SEM & $3.2 \pm 0.38$ & $\begin{array}{l}2.3 \pm 0.49 \\
P=\mathrm{NS}\end{array}$ & $2.9 \pm 0.15$ & $3.4 \pm 0.31$ & $\begin{array}{c}1.8 \pm 0.31 \\
-P<0.05\end{array}$ & & $P=\mathrm{NS}$ \\
\hline \multirow{7}{*}{ Decay-apparent $\mathrm{t} \frac{1}{2}, \min$} & 1 & 105 & 116 & 138 & 101 & 65 & 71 & \\
\hline & 2 & 128 & 71 & 85 & 84 & 116 & 98 & \\
\hline & 3 & 103 & 122 & 140 & 158 & 122 & 92 & \\
\hline & 4 & 90 & 113 & 97 & 79 & 168 & 77 & \\
\hline & 5 & 100 & 107 & 96 & 77 & 157 & 159 & \\
\hline & 6 & 115 & 95 & 109 & 92 & 157 & 97 & \\
\hline & Mean \pm SEM & $107 \pm 5.2$ & $\begin{array}{l}104 \pm 7.5 \\
P=\mathrm{NS}\end{array}$ & $\stackrel{111 \pm 8.9}{ }^{111}$ & $99 \pm \underbrace{12.5}$ & $\begin{array}{l}131 \pm 21 \\
-P=\mathrm{NS}\end{array}$ & 99土12.2 & $P=\mathrm{NS}$ \\
\hline
\end{tabular}

* The same men were used in both the $\mathrm{E}$ and $\mathrm{T}$ protocols.

‡ Results expressed as absolute increment in $\mathrm{LH}$ per pulse were similar and therefore omitted.

\& Significance refers to the comparison between the infusion period and both control periods simultaneously.

\section{The effect of DHT on LH secretion}

\section{MEAN LH}

DHT $(600 \mu \mathrm{g} / \mathrm{h})$ produced similar but somewhat greater suppression of mean $\mathrm{LH}$ than either $\mathrm{T}$ or $\mathrm{E}$ (Fig. 5). During the $6 \mathrm{~h}$ of DHT infusion, mean LH fell to $59 \pm 5.2 \%$ of control levels. Suppression (60士 $10.3 \%$ ) continued for an additional $6 \mathrm{~h}$ after the infusion was terminated. During the final $6 \mathrm{~h}$, mean $\mathrm{LH}$ returned to control levels as was observed after $\mathrm{T}$ and $\mathrm{E}$ infusions. The relatively greater effects of DHT on mean LH than $\mathrm{T}$, although suggesting a greater biologic potency of DHT, cannot be strictly evaluated since a different group of men were used in the DHT studies.

\section{Pulsatile Lh Release}

The effects on pulsatile $\mathrm{LH}$ release were intermediate between those observed during $\mathrm{T}$ and $\mathrm{E}$ infusion (Table III). Both amplitude and frequency were lowered during DHT infusion, but these differences were not statistically significant. Decay did not change in response to DHT infusion.

\section{DISCUSSION}

A variety of studies suggest that $T$ may serve as a prehormone for $\mathrm{E}$ in the hypothalamus and limbic system, and that these two steroids act in the CNS through a common mechanism (1-9). Even though this precursor to product relationship is firmly established, it was pertinent to consider whether the conversion of $\mathrm{T}$ to $\mathrm{E}$ was an absolute requirement for the biologic action of $T$ on the hypothalamic-pituitary axis. As observed in this study, the divergent effects of $\mathrm{T}$ and $\mathrm{E}$ on pulsatile $\mathrm{LH}$ secretion and LH-RH responsiveness provide evidence that $\mathrm{T}$ can modulate $\mathrm{LH}$ independently of $\mathrm{E}$ under the conditions of steroid administration utilized.

Analysis of the divergent effects of $E$ and $T$ on $L H$ secretion. E appeared to lower mean $\mathrm{LH}$ by reducing the amplitude of spontaneous LH pulses without significantly altering pulse frequency or decay. $T$, on the other hand, increased spontaneous LH pulse amplitude while reducing frequency. Interpretation of the significance of these observations requires an understanding of the physiologic mechanisms which initiate LH pulses and modulate pulse amplitude. A large number of studies 




Figure 4 Effect of $\mathrm{T}$ and $\mathrm{E}$ infusion on $\mathrm{LH}$ responsiveness to $\mathrm{LH}-\mathrm{RH}$. Each panel represents a separate study day in which LH levels ( \pm SEM) measured at 20-min intervals for $6 \mathrm{~h}$ are shown. $25 \mu \mathrm{g}$ of LH-RH was administered subcutaneously (indicated by the arrows) after $3 \mathrm{~h}$ of blood sampling during each study day. Note that the $E$ postinfusion control period (upper right panel, day 3, as indicated in the text) is also used as the $\mathrm{T}$ preinfusion control period (lower left panel) and is therefore identical.

in rodents and primates suggest that spontaneous $\mathrm{LH}$ pulses reflect the periodic secretion of LH-RH from the hypothalamus in response to firing of $\alpha$-adrenergically mediated CNS neurons $(14,28-31)$. If this consideration is correct, LH pulse amplitude could be modulated either by $(a)$ the amount of endogenous LH-RH released to initiate each spontaneous $\mathrm{LH}$ pulse or $(b)$ by the responsiveness of the pituitary to a given quantity of LH-RH. Administration of exogenous LH-RH allowed distinction between these two possibilities.

To assess the second possibility (the pituitary component of pulse modulation), "artificial" or nonspontaneous $\mathrm{LH}$ pulses were induced with exogenous $\mathrm{LH}-\mathrm{RH}$ and the effect of infused steroid on this parameter determined. In these experiments, $\mathrm{E}$ blunted the amplitude of "artificially induced" LH pulses to a similar extent, approximately one-half, as it reduced spontaneous $\mathrm{LH}$ pulse amplitude in the same men (Fig. 4, Table I). Other investigators have also demonstrated that $\mathrm{E}$ blocks LH-RH responsiveness in men $(32,33)$. These observations support the possibility that $E$ lowers the amplitude of spontaneous LH pulses by an effect on the pituitary. Furthermore, the overall rate of $\mathrm{LH}$ secretion could be lowered by this mechanism. These data, however, do not exclude the interpretation that $\mathrm{E}$ also exerts an hypothalamic effect as suggested by many studies (34, $35)$.

The mechanism by which $\mathrm{T}$ produced low frequency, high amplitude pulses did not appear to involve the pituitary since LH-RH responsiveness was not affected by this steroid. It is of interest that pulses with similar features are also observed during the luteal phase of the menstrual cycle in normal women when progesterone levels are high $(14,36)$. Since androgens and progestins exert many similar hormonal effects in rodents $(37)$, the possibility that $\mathrm{T}$ and progesterone produce high amplitude, low frequency pulses by a similar mechanism deserves further study.

It is recognized that interpretation of these data concerning divergent $\mathrm{E}$ and $\mathrm{T}$ effects must take into consideration the limitations introduced by the experimental methods used. In our studies, steroids were infused acutely and steady-state conditions were not achieved. Under these circumstances, the amount of steroid accumulating in critical brain or pituitary target tissues depends upon the rate of infusion of steroid into the blood and tissue extraction from it. Even though $T$ and $\mathrm{E}$ were both infused at equivalent physiologic rates (i.e. two times the respective production rates), the extraction of these steroids by brain or pituitary tissues could differ. Although not yet examined experimentally, it is possible that $E$ might enter brain at an enhanced rate because of lower binding to $\mathrm{T}$ estrogen-binding globulin at $37^{\circ} \mathrm{C}$. Alternately, the infusion of $\mathrm{T}$ (or DHT) might displace $\mathrm{E}$ from $\mathrm{T}$ estrogen-binding globulin and transi-

TABLE II

Effect of $T$ and E on LH-RH Responsiveness

\begin{tabular}{|c|c|c|c|c|c|c|c|}
\hline \multirow[b]{2}{*}{$\begin{array}{c}\text { L.H-RH responsiveness } \\
\text { parameter* }\end{array}$} & \multicolumn{3}{|c|}{ E protocol } & \multicolumn{3}{|c|}{$T$ protecol } & \multirow{2}{*}{$\begin{array}{c}\text { T vs. E } \\
\text { infusion } \\
\text { period- } \\
\text { significance }\end{array}$} \\
\hline & $\begin{array}{l}\text { Jay } 1 \\
\text { preinfusion }\end{array}$ & $\begin{array}{l}\text { Day } 2 \\
\text { infusion }\end{array}$ & $\begin{array}{c}\text { I)ay } 3 \ddagger \\
\text { postinfusion }\end{array}$ & $\begin{array}{l}\text { Day } 3 \neq \\
\text { meinfusion }\end{array}$ & $\begin{array}{l}\text { 1)ay } 4 \\
\text { infusion }\end{array}$ & $\begin{array}{l}\text { 1)ay } 5 \\
\text { postinfusion }\end{array}$ & \\
\hline $\begin{array}{l}\text { 3-h Mean } \$ \text { increase, } \% \\
\quad n=6\end{array}$ & $190 \pm 54$ & $\begin{array}{l}76 \pm 31 \\
-P<0.005\end{array}$ & $\begin{array}{r}170 \pm 33 \\
\end{array}$ & $170 \pm 3.3$ & $\begin{array}{l}217 \pm 59 \\
P=N S\end{array}$ & $\stackrel{175 \pm 49}{-}$ & $P<0.02$ \\
\hline $\begin{array}{l}\text { 3-h Mean } \delta \text { absolute rise, } n g / m l \\
\quad n=6\end{array}$ & $84 \pm 22$ & $\begin{array}{l}25 \pm 6.5 \\
-P<0.005\end{array}$ & $88 \pm 24$ & $88 \pm 24$ & $\begin{array}{r}85 \pm 29 \\
P=\mathrm{NS}\end{array}$ & $69 \pm 17$ & $P<0.05$ \\
\hline
\end{tabular}

* All data represent mean \pm SEM.

$\ddagger$ For purposes of statistical analysis, day 3 was utilized as both the postinfusion control for the E protocol and the preinfusion control for the $T$ protocol.

The m zan LH over $3 \mathrm{~h}$ after LH-RH is compared to mean LH over $3 \mathrm{~h}$ before LH-RH.

II Significance refers to the comparison between the infusion period and both control periods simultaneously (see text). 
ently increase free $\mathrm{E}$ levels. Although this later possibility is remote, it could produce the effects ascribed to the androgens.

The effect of steroid metabolism must also be considered in the interpretation of these infusion studies. As a result of peripheral aromatization, plasma levels of $\mathrm{E}$ increased from $28 \pm 3$ to $48 \pm 4 \mathrm{pg} / \mathrm{ml}$ during $\mathrm{T}$ infusions. Even greater increments in tissue concentrations of $\mathrm{E}$ might have been produced as well by the aromatization of $T$ in the hypothalamus. Since the effect of metabolism is to produce increments in both steroids during $\mathrm{T}$ infusion, it is pertinent to question whether the divergent effects of $\mathrm{T}$ and $\mathrm{E}$ on $\mathrm{LH}$ pulses observed in this study merely reflect the differences between low dose $\mathrm{E}$ resulting from the $\mathrm{T}$ infusion and high dose $\mathrm{E}$ infused directly. If the effects on pulses reflected such $\mathrm{E}$ dosage differences, one would expect that mean $\mathrm{LH}$ should have decreased to a greater extent during $E$ infusion than during $\mathrm{T}$ administration. However, we observed that $\mathrm{T}$ and $\mathrm{E}$ reduced mean $\mathrm{LH}$ similarly with respect to both time and magnitude of suppression. Based upon this indirect evidence, then, it is likely that the divergent effects of $\mathrm{T}$ and $\mathrm{E}$ reflect an independent action of $\mathrm{T}$ and that aromatization of $\mathrm{T}$ is not $\mathrm{an} a b-$ solute requirement for $\mathrm{LH}$ inhibition. However, for additional evidence, direct studies of the effects of androgens per se were performed to validate in men, observations previously studied extensively in rodents.

Additional studies supporting an independent effect of androgens on the hypothalamic-pituitary axis. In rodents, receptors which bind $\mathrm{T}$ with high affinity have been demonstrated in both the pituitary and hypothalamus (38). Rats insensitive to $\mathrm{T}$ because they lack cytoplasmic androgen receptors fail to exhibit LH suppression in response to $\mathrm{T}$, although they respond normally to exogenous E (39). Furthermore, DHT, a nonaromatizable androgen, inhibits $\mathrm{LH}$ in the rodent with a

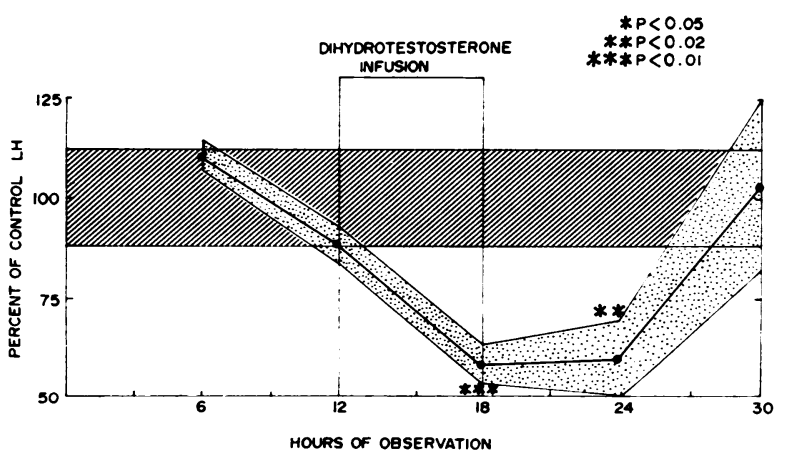

FigURE 5 Effect of DHT infusion on mean LH. 6-h mean LH levels are represented by the solid circles and the SEM by the shaded area. With this method (6-h mean LH levels), changes of greater than $\pm 12 \%$, cross-hatched area, are significant.
TABLE III

Effect of DHT on Pulsatile LH Release

\begin{tabular}{|c|c|c|c|}
\hline $\begin{array}{l}\text { Pulse analysis } \\
\text { parameter* }\end{array}$ & Preinfusion & Infusion & Postinfusion \\
\hline $\begin{array}{l}\text { Amplitude nadir-peak, } \% \\
\quad n=5\end{array}$ & $142 \pm 27$ & $\begin{array}{l}125 \pm 30 \\
P=\mathrm{NS} \ddagger\end{array}$ & $\underset{148 \pm 52}{-148}$ \\
\hline $\begin{array}{l}\text { Frequency, pulses } / 6 h \\
\quad n=5\end{array}$ & $3.0 \pm 0.22$ & $\begin{array}{l}2.6 \pm 0.67 \\
P=\mathrm{NS}\end{array}$ & $3.4 \pm 0.33$ \\
\hline $\begin{array}{l}\text { Decay-apparent } t \frac{1}{2}, \min \\
\quad n=5\end{array}$ & $72 \pm 7.4$ & $\begin{array}{l}90 \pm 18.6 \\
P=\mathrm{NS}\end{array}$ & 61 6.2 \\
\hline
\end{tabular}

* All data represent mean $\pm \mathrm{SEM}$.

$\ddagger$ Significance refers to the comparison between the infusion period and both control periods simultaneously (see text).

twofold greater potency than $T$ (40). When implanted directly into rat pituitary, this steroid also reduces the size and number of pituitary castration cells (41).

In man, other nonaromatizable androgens such as fluoxymestrone, high dose Danazol, and $2 \alpha$-methyl DHT are capable of suppressing plasma LH (or T) (42-44). Previous reports of DHT effects in man, however, have been conflicting. Stewart-Bentley et al. demonstrated LH suppression in normal men with administration of 7 and $35 \mathrm{mg} /$ day of DHT (4). On the other hand, Sherins and Loriaux (3) and Faiman and Winter (45) could not demonstrate this effect. Neither of these latter studies took into account the pulsatile nature of $\mathrm{LH}$ release and consequently, blood was collected too infrequently for precise assessment of mean LH levels. Since pulsatile hormone release continues during DHT administration, $20-30 \%$ changes in mean $\mathrm{LH}$ cannot be easily detected in the face of much larger spontaneous LH fluctuations without multiple sampling techniques.

In this study, therefore, blood samples were collected at 20-min intervals before, during, and after DHT infusion. This method of examination allowed the demonstration of significant LH suppression during DHT administration (Fig. 5). Consistent with the 1.5-2.5-fold greater potency of DHT than $\mathrm{T}$ in bioassay systems (46), the reduction observed in mean $\mathrm{LH}$ appeared slightly greater during DHT than $\mathrm{T}$ infusion. These data provide direct support in men that androgens may exert suppressive effects on $\mathrm{LH}$ secretion without first being converted to estrogens.

The differences between the effects of $\mathrm{T}$ and DHT on LH pulses observed in this study were unexpected and possible explanations can only remain speculative. The differences in circulating levels of $\mathrm{E}$ during $\mathrm{T}$ and DHT infusion (Fig. 2A, B) could provide a possible explanation. This would imply an interaction between the independent effects of $\mathrm{T}$ and $\mathrm{E}$ on $\mathrm{LH}$ secretion. Alternately, too few subjects may have been studied to determine statistically significant effects on LH pulses. Identification of the reason for these differences, however, is be- 
yond the scope of this study and not critical in answering the single question which prompted this investigation.

Acute and chronic components of $L H$ negative feedback. In this study, a method was developed which allowed examination of the acute effects of gonadal steroids on $\mathrm{LH}$ secretion. While previous observations suggested that the negative feedback system controlling $\mathrm{LH}$ responds relatively slowly in men $(3,4,47)$, the present study demonstrates that mean $\mathrm{LH}$ levels fall within $6 \mathrm{~h}$ of $\mathrm{T}$ or $\mathrm{E}$ infusion and that responsiveness to $\mathrm{LH}-\mathrm{RH}$ is reduced by $\mathrm{E}$ within $3 \mathrm{~h}$. Acute components of negative feedback control of LH, therefore, do exist in men.

Since we examined the short-term component of this system exclusively, it is pertinent to consider whether the acute effects of $\mathrm{T}$ and $\mathrm{E}$ may differ from their more chronic effects. Other studies in men support such a possibility. Von zur Mühlen and Köbberling demonstrated (as in the present investigation) that acute $\mathrm{T}$ injection does not alter the response to LH-RH in man, whereas chronic treatment blunts this effect (48). As a possible explanation for this observation, chronic $T$ administration may decrease endogenous LH-RH secretion and result in reduced synthesis, and, ultimately, pituitary content of LH. Under these circumstances, response to exogenous LH-RH might be blunted. On the other hand, $T$ may have a direct pituitary effect when administered chronically.

In conclusion, we observed similar suppression of mean $\mathrm{LH}$ with physiologic infusions of $\mathrm{T}$ and $\mathrm{E}$, but divergent effects on pulsatile $\mathrm{LH}$ release and $\mathrm{LH}-\mathrm{RH}$ responsiveness. In addition, an androgen which cannot be converted into an estrogen, DHT, was capable of suppressing mean LH levels. These data provided both direct and indirect evidence to answer the single question asked in this study and suggested that $T$ does not require aromatization to $E$ for inhibition of $\mathrm{LH}$ secretion in men.

\section{ACKNOWLEDGMENTS}

The reagents for the LH radioimmunoassay system were generously supplied by the National Pituitary Agency. Dr. Guy Rochefort of the Ayerst Laboratories (New York) provided the synthetic LH-RH (AY 24031) for use in this study. Appreciation is expressed to Mr. Barry Boyer and Mr. Amel P. French for their excellent technical assistance and to Mrs. Marlene Brinser for preparation of the manuscript. Critical review of the manuscript by Dr. C. Wayne Bardin and Dr. Howard E. Kulin is gratefully acknowledged.

This work was supported in part by grant HD05276 and Special Fellowship HD52461 of the NIH Institute of Child Health, and Human Development.

\section{REFERENCES}

1. Gorski, R. A., and C. A. Barraclough. 1963. Effects of low dosages of androgen on the differentiation of hypo- thalamic regulatory control of ovulation in the rat. $E_{n-}$ docrinology. 73 : 210-216.

2. Gorski, R. A. 1963. Modification of ovulatory mechanisms by postnatal administration of estrogen to the rat. Am. J. Physiol. 205 : 842-844.

3. Sherins, R. J., and D. L. Loriaux. 1973. Studies on the role of sex steroids in the feedback control of FSH concentrations in men. J. Clin. Endocrinol. Metab. 36: 886-893.

4. Stewart-Bentley, M., W. Odell, and R. Horton. 1974. The feedback control of luteinizing hormone in normal adult men. J. Clin. Endocrinol. Metab. 38: 545-553.

5. Naftolin, F., K. J. Ryan, and Z. Petro. 1971. Aromatization of androstenedione by the diencephalon. J. Clin. Endocrinol. Metab. 33: 368-370.

6. Naftolin, F., K. J. Ryan, and Z. Petro. 1971. Aromitization of androstenedione by limbic system tissue from human foetuses. J. Endocrinol. 51 : 795-796.

7. Naftolin, F., K. J. Ryan, and Z. Petro. 1972. Aromatization of androstenedione by the anterior hypothalamus of adult male and female rats. Endocrinology. 90: 295-298.

8. Ryan, K. J., F. Naftolin, V. Reddy, F. Flores, and Z. Petro. 1972. Estrogen formation in the brain. Am. J. Obstet. Gynecol. 114: 454-460.

9. Reddy, V. V. R., F. Naftolin, and K. J. Ryan. 1973. Aromatization in the central nervous system of rabbits: Effects of castration and hormone treatment. Endocrinology. 92: 589-594.

10. McEwen, B. S., and D. W. Pfaff. 1970. Factors influencing sex hormone uptake by rat brain regions. I. Effects of neonatal treatment, hypophysectomy, and competing steroid on estradiol uptake. Brain Res. 21: 1-16.

11. McEwen, B. S., D. W. Pfaff, and R. E. Zigmond. 1970. Factors influencing sex hormones uptake by rat brain regions. II. Effects of neonatal treatment and hypophysectomy on testosterone uptake. Brain Res. 21: 1728.

12. McEwen, B. S., D. W. Pfaff, and R. E. Zigmond. 1970. Factors influencing sex hormone uptake by rat brain regions. III. Effects of competing steroids on testosterone uptake. Brain Res. 21 : 29-38.

13. Stumpf, W. E. 1970. Estrogen-neurons and estrogenneuron systems in the periventricular brain. $\mathrm{Am}$. J. Anat. 129: 207-217.

14. Santen, R. J., and C. W. Bardin. 1973. Episodic luteinizing hormone secretion in man. Pulse analysis, clinical interpretation, physiologic mechanisms. J. Clin. Invest. 52: 2617-2628.

15. Bartke, A., R. E. Steele, N. Musto, and B. V. Caldwell. 1973. Fluctuations in plasma testosterone levels in adult male rats and mice. Enḋocrinology. 92: 12231228.

16. Robertson, H. A., T. C. Smeaton, and R. Durnford. 1972. A method for the extraction, separation and estimation of unconjugated estrone, estradiol-17 $\alpha$ and estradiol-17 $\beta$ in plasma. Stcroids. 20: $651-667$.

17. Nankin, H. R., and P. Troen. 1971. Repetitive luteinizing hormone elevations in serum of normal men. $J$. Clin. Endocrinol. Metab. 33: 558-560.

18. Naftolin, F., S. S. C. Yen, and C. C. Tsai. 1972. Rapid cycling of plasma gonadotropins in normal men as demonstrated by frequent sampling. Nat. New Biol. 236: 92-93.

19. Rubin, R. T., A. Kales, R. Adler, T. Fagan, and W. Odell. 1971. Gonadotropin secretion during sleep in 
normal adult men. Science (Wash. D. C.). 175: 196198.

20. Boyar, R., M. Perlow, L. Hellman, S. Kapen, and E. Weitzman. 1972. Twenty-four hour pattern of luteinizing hormone secretion in normal men with sleep stage recording. J. Clin. Endocrinol. Metab. 35: 73-81.

21. Krieger, D. T., R. Ossowski, M. Fogel, and W. Allen. 1972. Lack of circadian periodicity of human serum FSH and LH levels. J. Clin. Endocrinol. Metab. 35: 619-623.

22. Nankin, H. R., and P. Troen. 1972. Overnight patterns of serum luteinizing hormone in normal men. J. Clin. Endocrinol. Metab. 35: 705-710.

23. Rebar, R., S. S. C. Yen, G. Vandenberg, F. Naftolin, Y. Ehara, S. Engblom, K. J. Ryan, J. Rivier, M. Amoss, and R. Guillemin. 1973. Gonadotropin responses to synthetic LRF: Dose-response relationship in men. J. Clin. Endocrinol. Metab. 36: 10-16.

24. Baird, D., R. Horton, C. Longcope, and J. F. Tait. 1968. Steroid prehormones. Perspect. Biol. Med. 11: $384-421$.

25. Ito, T., and R. Horton. 1971. The source of plasma dihydrotestosterone in man. J. Clin. Invest. 50: 16211627.

26. Dufau, M. L., A. Dulmanis, K. J. Catt, and B. Hudson. 1970. Measurement of plasma estradiol-17 $\beta$ by competitive binding assay employing pregnancy plasma. J. Clin. Endocrinol. Metab. 30: 351-356.

27. Siegel, S. 1956. Nonparametric Statistics for the Behavioral Sciences. McGraw-Hill Book Co., New York. 68-74.

28. Bhattacharya, A. N., D. J. Dierschke, T. Yamaji, and E. Knobil. 1972. The pharmacologic blockade of the circhoral mode of $\mathrm{LH}$ secretion in the ovariectomized Rhesus monkey. Endocrinology. 90: 778-786.

29. Blake, C. A., and C. H. Sawyer. 1974. Effects of hypothalamic deafferentation on the pulsatile rhythm in plasma concentrations of luteinizing hormone in ovariectomized rats. Endocrinology. 94: 730-736.

30. Seyler, L. E., Jr., and S. Reichlin. 1974. Episodic secretion of luteinizing hormone-releasing factor (LRF) in the human. J. Clin. Endocrinol. Metab. 39: 471-478.

31. Bremner, W. J., and C. A. Paulsen. 1974. Two pools of luteinizing hormone in the human pituitary: Evidence from constant administration of luteinizing hormonereleasing hormone. J. Clin. Endocrinol. Metab. 39: 811815.

32. Seyler, L. E. Jr., E. Canalis, and S. Reichlin. 1974. Effect of stilbestrol on LH secretory response to LRH in men and women. Proceedings of the 56th Meeting of The Endocrine Society. A-82. (Abstr.)

33. Cole, E. N., A. R. Boyns, and D. E. H. Llewelyn. 1974. Acute effects of gonadal steroids on pituitary sensitivity in healthy men. J. Endocrinol. 63: 49P. (Abstr.)

34. Seyler, L. E., Jr., and S. Reichlin. 1974. Feedback regulation of circulating LRF concentrations in men. J. Clin. Endocrinol. Metab. 39: 906-912.

35. Libertun, C., K. J. Cooper, C. P. Fawcett, and S. M.
McCann. 1974. Effects of ovariectomy and steroid treatment on hypophyseal sensitivity to purified LH-releasing factor (LRF). Endocrinology. 94: 518-525.

36. Yen, S. S. C., C. C. Tsai, F. Naftolin, G. Vandenberg, and L. Ajabor. 1972. Pulsatile patterns of gonadotropin release in subjects with and without ovarian function. J. Clin. Endocrinol. Metab. 34: 671-675.

37. Mowszowicz, I., D. E. Bieber, K. Y. Chung, L. P. Bullock, and C. W. Bardin. 1974. Synandrogenic and antiandrogenic effect of progestins: Comparison with nonprogestational antiandrogens. Endocrinology. 95: 1589-1599.

38. Naess, O., A. Attramadal, and A. Aakvaag. 1975. Androgen binding proteins in the anterior pituitary, hypothalamus, preoptic area and brain cortex of the rat. Endocrinology. 96: 1-9.

39. Sherins, R. J., L. Bullock, V. L. Gay, T. VanhaPerttula, and C. W. Bardin. 1971. Plasma LH and FSH levels in the androgen insensitive pseudohermaphroditic rat. Responses to steroid administration. Endocrinology. 88: 763-770.

40. Swerdloff, R. S., P. C. Walsh, and W. D. Odell. 1972. Control of $\mathrm{LH}$ and FSH secretion in the male. Evidence that aromatization of androgens to estradiol is not required for inhibition of gonadotropin secretion. Steroids. 20: 13-22.

41. Kingsley, T. R., and E. M. Bogdanove. 1973. Direct feedback of androgens: Localized effects of intrapituitary implants of androgens on gonadotrophic cells and hormone stores. Endocrinology. 93: 1398-1409.

42. Bardin, C. W., G. T. Ross, and M. B. Lipsett. 1967. Site of action of clomiphene citrate in men: A study of the pituitary-Leydig cell axis. J. Clin. Endocrinol. Metab. 27 : 1558-1564.

43. Davis, T. E., M. B. Lipsett, and S. G. Korenman. 1965. Suppression of testosterone production by physiologic doses of $2 \alpha$-methyl dihydrotestosterone propionate. J. Clin. Endocrinol. Metab. 25: 476-479.

44. Sherins, R. J., H. M. Gandy, T. W. Thorslund, and C. A. Paulsen. 1971. Pituitary and testicular function studies. I. Experience with a new gonadal inhibitor, $17 \alpha$-pregn-4-en-20-yno-(2,3-d) isoxazol-17-ol (Danazol). J. Clin. Endocrinol. Metab. 32: 522-531.

45. Faiman, C., and J. S. D. Winter. 1974. The control of gonadotropin secretion in complete testicular feminization. J. Clin. Endocrinol. Metab. 39: 631-638.

46. Bardin, C. W., and J. A. Mahoudeau. 1970. Dynamics of androgen metabolism in women with hirsutism. Ann. Clin. Res. 2 : 251-262.

47. Lee, P. A., R. B. Jaffe, A. R. Midgley, Jr., F. Kohen, and G. D. Niswender. 1972. Regulation of human gonadotropins. VIII. Suppression of serum LH and FSH in adult males following exogenous testosterone administration. J. Clin. Endocrinol. Metab. 35: 636641.

48. von zur Mühlen, A., and J. Köbberling. 1973. Effect of testosterone on the $\mathrm{LH}$ and $\mathrm{FSH}$ release induced by LH-releasing factor (LRF) in normal men. Horm. Metab. Res. 5 : 266-270. 